University of Nebraska - Lincoln

DigitalCommons@University of Nebraska - Lincoln

The NASA Land-Cover/Land-Use Change (LCLUC) Program's

Support of the Northern Eurasia Earth Science Partnership Initiative (NEESPI): Focus on Non-boreal Europe

Garik Gutman

NASA

Follow this and additional works at: https://digitalcommons.unl.edu/nasapub

Part of the Physical Sciences and Mathematics Commons

Gutman, Garik, "The NASA Land-Cover/Land-Use Change (LCLUC) Program's Support of the Northern Eurasia Earth Science Partnership Initiative (NEESPI): Focus on Non-boreal Europe" (2009). NASA

Publications. 9.

https://digitalcommons.unl.edu/nasapub/9

This Article is brought to you for free and open access by the National Aeronautics and Space Administration at DigitalCommons@University of Nebraska - Lincoln. It has been accepted for inclusion in NASA Publications by an authorized administrator of DigitalCommons@University of Nebraska - Lincoln. 


\title{
The NASA Land-Cover/Land-Use Change (LCLUC) Program's Support of the Northern Eurasia Earth Science Partnership Initiative (NEESPI): Focus on Non-boreal Europe
}

\section{Garik Gutman}

NASA Headquarters, Land Cover/Land-Use Change Program, 300 E St. SW, Washington, DC 20546, USA, E-mail:ggutman@noaa.gov

\begin{abstract}
Currently, the Northern Eurasia Earth Science Partnership Initiative (NEESPI) includes over 120 international projects involving more than 200 scientific institutions from over 30 countries. The program involves national government agencies, academia and private organizations in the U.S., Europe, Japan and Northern Eurasia (Gutman 2007). The NEESPI science is directed at evaluating the role of anthropogenic impacts on the Northern Eurasia ecosystems, the hemispheric-scale interaction and assessing how future human actions would affect the global climate and ecosystems of the region. Projections of the consequences of global changes for regional environment in Northern Eurasia are also in the center of the scientific foci of this initiative. The Land-Cover/Land-Use Change (LCLUC) Program is an interdisciplinary science program in the Earth Science Division of the Science Mission Directorate supporting several regional initiatives, including NEESPI. The NASA LCLUC currently funds over 30 NEESPI projects. The NEESPI program links to several international projects, such as GLP, iLEAPS and others, under major international programs: IGBP and WCRP. The NEESPI covers a large geographic domain, which includes the former Soviet Union, northern China, Mongolia, Scandinavia and Eastern Europe. This contribution provides a short description of the ongoing NEESPI studies in the non-boreal European sub-region of the NEESPI geographic domain that are supported by the NASA LCLUC program. More information on the projects can be found at http://neespi.org and http://lcluc.hq.nasa.gov.
\end{abstract}

Keywords: land cover, land use change, non-boreal Eastern Europe

\section{Introduction}

The National Aeronautics and Space Administration (NASA) is among the NEESPI major partners, with several NASA programs contributing to this initiative. The NASA LCLUC Program has been supporting the NEESPI since its 
inception. The non-boreal Europe is of particular interest for studying LCLUC processes due to the dramatic socio-economic shifts in the former Soviet-block countries during the past 17 years. The rapid land-use and land-cover changes observed from space and their impacts on the environment and ecosystems are the focus of several NEESPI projects encompassing various sectors, including forestry, coastal zone and agriculture. The changes in water quality and vegetation-cover and the shifts in agricultural practices with the consequent changes in carbon emissions in non-boreal zone of Northern Eurasia are especially important in the NEESPI science agenda.

In addition to supporting research projects NASA also contributes to the NEESPI by supporting the NEESPI Project Scientist, the International Project Office and in organizing and sponsoring regional NEESPI meetings, such as the non-boreal Europe meeting in Odessa in September 2008. Additionally, NASA is playing the leading role in facilitating access to data and derived products to NEESPI participants.

\section{The global land surveys}

Regional studies in the LCLUC program in general, and in the NEESPI projects, in particular, strongly depend on the availability of Landsat and Landsat-like data. To satisfy the data needs for regional and global studies USGS and NASA are jointly developing a Global Land Survey (GLS)-2005 dataset (also known as the Mid-Decadal dataset) similar to the Geocover 2000, which has been available for several years. The goal is to develop a global orthorectified dataset from Landsat observations based on measurements during the 2004-2007 period with 30-m spatial resolution. The project uses Landsat-5 ground station data where available, Landsat-7 composites, and ASTER and EO-1/ALI to fill the gaps and over islands (Gutman et al. 2008). The completion of the GLS-2005 is planned for the end of 2008. LCLUC products based on this new dataset are being developed in the projects selected recently by NASA. NEESPI scientists will make use of the developed land-cover classification and land-cover change products as soon as they become available.

\section{The NEESPI non-boreal projects}

Gutman (2007) described the early developments in the NEESPI program. Most of the studies at the early stage were devoted to the boreal zone. Several projects, however, were focused on studying processes in the European non-boreal zone. Below are some results from these investigations. 
A team consisting of scientists at Columbia University and IIASA with Ukrainian collaborators conducted a project on carbon, climate and managed land in Ukraine. The project put forward the following science question: What are the consequences to carbon storage from changes in agricultural management due to both socio-economic trends and climate change impacts? This study found no strong dependence on fertilizer use (soils are rich, less dependent on fertilizer application for optimal crop production), but significant dependence on irrigation in southern regions (Tubiello et al. 2007a, b). Projections of changes in suitability of spring and winter wheat in Ukraine, under both rainfed and irrigated conditions, were computed for 2020, 2050 and 2080 projections with four different GCMs, and compared to the current climate (Tubiello and Fischer 2007).

An international team led by Boston University conducted a project studying the effects of land-use change on terrestrial carbon budgets in the Black Sea region. The region was selected because of reported intensive land-use/land-cover change activities following the collapse of the Soviet Union, as well as prior lack of attention to the temperate zone within NEESPI. The results indicate that both Romania and Georgia have low intensity forest-cover change between 1990 and 2000 but this activity increases with continued changes in forest management rules and political priorities in both countries. Remote sensing based analysis of Black Sea forests of Turkey at the southernmost limit of the NEESPI domain, on the other hand, shows very little to no change over the same time period, primarily because of strong government control of forest resources and obvious lack of postsoviet transformation. When these changes are incorporated within a well-established carbon model, results suggest that forests of all three countries act as a carbon sink at least for a few more decades (Baccini et al. 2008). These results improve our current knowledge of the region in terms of land-use dynamics and minimize the uncertainties associated with the carbon cycle dynamics related to land-use change. This research also included a significant methodological component to improve current ability to monitor change in temperate forests and also many other environments using remote sensing. For example, evaluation of the concept of signature extension from this region to other environments suggests that image seasonality, choice of atmospheric correction method, and input variables significantly affect classification accuracy across time and space. The gained experience helps advancing methods for semi-automated monitoring of environmental change.

The University of Wisconsin, Madison, in collaboration with German (Humboldt University in Berlin) and East European scientists, conducted a project on socioeconomic effects on biodiversity in post-Soviet land-cover change in Eastern Europe during the last decade and developed some future scenarios. The results showed marked differences in forest cover, dominant forest species, and agricultural fragmentation. Project participants conclude that socialist forest management explains these differences. Post-socialist land-cover change was greatest in Ukraine, where there was high agricultural fragmentation and widespread earlysuccession shrublands indicating extensive land abandonment. The abundance and pattern of arable land and grassland were attributed to land tenure in socialist 
times and economic transition since 1990. These results suggest that broad-scale socioeconomic and political factors are of major significance for land-cover patterns in Eastern Europe. (Kuemmerle et al. 2007)

Flooding related to land-cover changes in the Carpathian mountains has been studied by University of Maryland's Appalachian Laboratory with the above mentioned Humboldt University-University of Wisconsin group in collaboration with scientists in Eastern Europe. The goal is to assess the potential hydrologic ramifications of recent changes associated with deforestation in this region. An analytical remote-sensing based approach is applied to the assessment of landcover change in the High Tatras Mountains of Slovakia based on the forest disturbance index of Healey et al. (2005) and several other methods (e.g., Townsend et al. 2004; de Beurs and Townsend 2008). The team relates the landscape properties to differences in stream discharge among watersheds with differing disturbance histories. The Landsat images for the entire High Tatras region for three time periods $(1990,2000,2005)$ are being processed. Historical daily stream discharge data for six catchments and daily precipitation data for 12 stations in this region were obtained from the Slovak Hydro-meteorological Institute. The next step is to conduct broader analysis of land-cover change using data generated by the German-University of Wisconsin team (Kuemmerle et al. $2007,2008)$ to identify forested watersheds that have experienced relatively large changes in forest cover (either losses or gains) that may be related to increases in flooding in the Carpathian region. At present, that team has completed mapping for much of the region (especially Ukraine and Poland), with other areas still in development. The work on image acquisition and processing, including adding information from Slovakia to their database, is ongoing.

In a pilot project on Latvia, land-cover and land-use dynamics in 90,000-ha Gauja National Park (GNP) were examined for Latvia's Soviet-to-post-Soviet transition period from the mid-1980s through 2002. Land-cover change in the Park was assessed through analyses of Landsat TM images in conjunction with multiple ancillary Geographic Information Systems (GIS) data layers. Changes in landcover composition and patterns were measured using post-classification change analyses and by computing landscape pattern metrics. Statistical regression models were developed to determine effects on the landscape of spatially explicit variables representing social, biophysical, geographic, and political drivers of land-cover change in GNP. Qualitative interviews were conducted to investigate GNP stakeholder group interests, and results from a landowner survey conducted by the GNP Administration were geocoded and statistically analyzed with respect to geographically explicit variables to understand important factors affecting landowner attitudes to GNP land-use policies. Land-cover change analyses showed an increase in forest cutting immediately after Latvia's independence in 1991, and, following, a consistent overall growth in forested lands, particularly in the more protected zones of the Park. A decrease in the amount of fields and meadows was evident since Latvian independence, resulting in a deterioration of Latvia's cultural landscape and the associated biodiversity. Regression analyses 
showed that the most important predictor variables of the type of land-cover change, on a per pixel basis, were the Park management zones in which the land was located, the distance from large water bodies, the distance to the nearest road, the municipality, and the slope of the land. Contrary to expectations, cross-tab analyses showed that landowners in zones with more land-use restrictions were more likely to be supportive of GNP land-use policies than were landowners in zones with fewer land-use restrictions (Taff 2005).

Land-cover/land-use change effects on water quality in Dnieper and Don river basins has been the subject of a project conducted at the University of Nebraska and South Dakota State University with collaborators in Ukraine and Russia with two objectives: (1) to assess the magnitude and variability of the linkage between LCLUC and dynamics of surface water quality, and (2) to develop the capability to use SeaWiFS and MODIS data to retrieve chlorophyll-a and suspended solids in turbid productive waters. The study area includes Don River Basin $\left(450,000 \mathrm{~km}^{2}\right)$ and Dnieper River Basin (530,000 $\mathrm{km}^{2}$ ) and uses 1982-2000 AVHRR NDVI datasets. For 2003 MODIS NBAR NDVI data are being used. Selected Landsat scenes 1974-2006 are also used in this study, especially studying water quality: 1982-2001 - MSS and TM Landsat data. For the period since 1997 SeaWiFS data are used and from 2001 to present the project employs MODIS data. The methodology is based on the statistical framework to partition the variation arising from interannual climatic variability, changes in sensors, and of institutional change (de Beurs and Henebry 2005). To retrieve chlorophyll-a concentrations from remotely sensed data an inversion technique is used described in Dall'Olmo and Gitelson (2005, 2006) and Gitelson et al. (2008). This study produced characterization of land surface phenologies in Don and Dnieper river basins using AVHRR image time series and developed calibration and validation of model for chlorophyll retrieval in a wide range of optical properties of water bodies. The current effort includes using Landsat image time series since 1982 to investigate changes in land cover at finer spatial resolution in areas of significant change identified in the coarser grained analysis. Additionally, the work will develop a change product for chlorophyll-a and total suspended matter concentrations in key Dnieper and Don reservoirs and Gulf of Taganrog. Within the project, atmospheric correction of MODIS ocean red and NIR radiances and algorithms calibration for chlorophyll and total suspended matter retrieval from MODIS imagery (see http://snr.unl.edu/neespi). Recently, two more projects on the non-boreal European NEESPI sub-region joined the program: a additional project on the changes in temperate forests was launched at the University of Wisconsin with European collaborators and a continuation project on interactions between land use and hydrology has started at the University of New Hampshire in collaboration with Russian scientists. Note that as a requirement to enter the program every NEESPI project has collaborators in the NEESPI region. The program is also growing; its members interact and build new teams and produce new exciting results. A synthesis paper of the results on non-boreal European NEESPI sub-region is expected over the course of next few years. 


\section{References}

Baccini, A., C.E. Woodcock, R. Houghton, J. Hackler, M. Ozdogan, V. Gancz and V. Blujdea (2009) Carbon budgets in Romanian forests, Proceedings of the National Academy of Sciences, in review.

de Beurs, K.M. and G.M. Henebry (2005) A statistical framework for the analysis of long image time series. International Journal of Remote Sensing 26:1551-1573.

de Beurs, K.M. and P.A. Townsend (2008) Estimating the effect of gypsy moth defoliation using MODIS. Remote Sensing of Environment 112:3983-3990.

Dall'Olmo, G. and A.A. Gitelson (2005) Effect of bio-optical parameter variability on the remote estimation of chlorophyll-a concentration in turbid productive waters: experimental results. Applied Optics 44:412-422. Dall'Olmo, G. and A.A. Gitelson (2006) Effect of bio-optical parameter variability and uncertainties in reflectance measurements on the remote estimation of chlorophyll-a concentration in turbid productive waters: modeling results. Applied Optics 45:3577-3592.

Eshleman, K.N., B.E. McNeil and P.A. Townsend (2009) Validation of a remote-sensing based index of forest disturbance using streamwater nitrogen data. Ecological Indicators, in press.

Gitelson, A.A., G. Dall'Olmo, W. Moses, D.C. Rundquist, T. Barrow, T.R. Fisher, D. Gurlin and J. Holz (2008) A simple semi-analytical model for remote estimation of chlorophyll-a in turbid waters: validation. Remote Sensing of Environment 112:3582-3593, doi:10.1016/j.rse. 2008.04.015.

Gutman, G. (2007) Contribution of the NASA land-cover/land-use change program to the Northern Eurasia earth science partnership initiative: an overview. Journal of Global and Planetary Change 56:235-247.

Gutman, G., R. Byrnes, J. Masek, S. Covington, C. Justice, S. Franks and R. Headley (2008) Towards monitoring land-cover and land-use changes at a global scale: the Global Land Survey 2005. Photogrammetric Engineering and Remote Sensing 74(1):6-10.

Healey, S.P., W.B. Cohen, Z.Q. Yang and O.N. Krankina (2005) Comparison of tasseled capbased landsat data structures for use in forest disturbance detection. Remote Sensing of Environment 97:301-310.

Kuemmerle, T., P. Hostert, V.C. Radeloff, K. Perzanowski and I. Kruhlov (2007) Post-socialist forest disturbance in the Carpathian border region of Poland, Slovakia, and Ukraine. Ecological Applications 17:1279-1295.

Kuemmerle, T., P. Hostert, V.C. Radeloff, S. van der Linden, K. Perzanowski and I. Kruhlov (2008) Cross-border comparison of post-socialist farmland abandonment in the Carpathians. Ecosystems 11:614-628.

Taff, G. (2005) Conflict between global and local land-use values in Latvia's Gauja national park. Landscape Research 30(3):415-430.

Townsend, P.A., K.N. Eshleman and C. Welcker (2004) Relationships between stream nitrogen concentrations and intensity of forest disturbance following gypsy moth defoliation in 20002001. Ecological Applications 14:504-516.

Townsend, P.A., D.P. 143 Helmers, C.C. Kingdon, B.E. McNeil, K.M. de Beurs and K.N. Eshleman Changes in the extent of surface mining and reclamation in the Central Appalachians: 19762006. Remote Sensing of Environment, 113:62-72, doi: 10.1016/j.res.2008.08.012.

Tubiello, F.N. and G. Fischer (2007) Reducing climate change impacts on agriculture: Global and regional effects of mitigation, 1990-2080. Technological Forecasting and Social Change 74:1030-1056.

Tubiello, F.N., J.F. Soussana, M. Howden and W. Easterling (2007a) Crop and pasture response to climate change; fundamental processes. Proceedings of the National Academy of Sciences 104:1968619690.

Tubiello, F.N., J.A. Amthor, K. Boote, M. Donatelli, W. Easterling, G. Fischer, R. Gifford, M. Howden, J. Reilly and C. Rosenzweig (2007b) Crop response to elevated CO2 and world food supply. European Journal of Agronomy 26(3):215-223. 